\title{
Identifikasi Senyawa Natrium Benzoat pada Cabai Merah Giling yang Dijual di Pasar Raya Kota Padang
}

\author{
Zakiya Zar'a', Elmatris Sy', Laila Isrona ${ }^{3}$ \\ ${ }^{1}$ Fakultas Kedokteran Universitas Andalas, Padang \\ ${ }^{2}$ Bagian Kimia Fakultas Kedokteran Universitas Andalas, Padang \\ ${ }^{3}$ Bagian Pendidikan Kedokteran Fakultas Kedokteran Universitas Andalas, Padang
}

\begin{abstract}
A B S T R A C T
Latar Belakang. Cabai merah merupakan bumbu masak yang banyak dikonsumsi masyarakat, baik dalam bentuk buah maupun hasil gilingan. Cabai merah giling memiliki daya simpan yang rendah dan mudah ditumbuhi mikroorganisme perusak, untuk itu digunakan pengawet berupa natrium benzoat yang dapat menghambat kerusakan cabai. Batasan penggunaan natrium benzoat pada cabai diatur dalam Peraturan Kepala BPOM No. 36 Tahun 2013 maksimal 0,6 g/kg. Objektif. Mengetahui kadar penggunaan natrium benzoat pada cabai merah giling yang dijual di Pasar Raya Kota Padang, berdasarkan standar ketetapan BPOM.

Metode. Penelitian ini merupakan penelitian deskriptif yang dilakukan di UPTD Balai Laboratorium Kesehatan Sumatera

Method. The type of research is descriptive research, conducted at UPTD Balai Laboratorium Kesehatan Sumatera Barat from September 2019 to July 2020. The research sample consisted of 35 samples obtained by total sampling method.

Result. All of grinded red chilies used as sample were positive containing sodium benzoate. Average levels of sodium benzoate in grinded red chili is $0,144 \mathrm{~g} / \mathrm{kg}$. The level of sodium benzoate in each sample is below National Agency of Drug and Food Control Republic of Indonesia standard $(<0,6 \mathrm{~g} / \mathrm{kg})$.

Conclusion. All samples of grinded red chilies were positive containing sodium benzoate with appropriate levels as stated in National Agency of Drug and Food Control Republic of Indonesia provision.
\end{abstract} Barat dari bulan September 2019 hingga Juli 2020. Sampel penelitian berjumlah 35 sampel yang diperoleh dengan teknik total sampling.

Hasil. Penelitian menggunakan $\mathrm{FeCl}_{3} 5 \%$ dan pengujian kadar natrium benzoat sampel menggunakan spektrofotometer UVVisible. Semua cabai merah giling yang menjadi sampel, positif mengandung natrium benzoat. Kadar rata-rata natrium benzoat pada cabai merah giling adalah $0,144 \mathrm{~g} / \mathrm{kg}$. Kadar natrium benzoat pada setiap sampel berada di bawah standar ketetapan BPOM $(<0,6 \mathrm{~g} / \mathrm{kg})$.

Kesimpulan. Semua sampel cabai merah menunjukkan hasil positif mengandung natrium benzoat dan memenuhi standar ketetapan BPOM $(<0,6 \mathrm{~g} / \mathrm{kg})$.

Kata kunci: cabai merah giling, natrium benzoat, spektrofotometer UV-Visible.

Background. Red chili is a spice that is consumed by many people, in the form of fruit or grinded. Grinded red chili has a low shelf life and is easily overgrown by destructive microorganisms, therefore it needs preservatives such as sodium benzoate which can inhibit the destruction. Based on regulation of National Agency of Drug and Food Control Republic of Indonesia No. 36/2013, the maximum limit of sodium benzoate in seasoning is $0.6 \mathrm{~g} / \mathrm{kg}$.

Objective. to identify sodium benzoate and its level in grinded red chili has been sold in Pasar Raya Padang based on BPOM standard.
Keywords: grinded red chili, sodium benzoate, Spectrophotometer UV-Visible.

\section{Apa yang sudah diketahui tentang topik ini?}

Natrium benzoat lebih banyak digunakan sebagai pengawet dalam makanan karena kelarutannya mencapai 200 kali kelarutan asam benzoat di dalam air.

\section{Apa yang ditambahkan pada studi ini?}

Seluruh cabai merah giling yang menjadi sampel, positif mengandung natrium benzoat dengan kadar yang memenuhi standar ketetapan BPOM dalam Peraturan Kepala Badan Pengelola Obat dan Makanan nomor 36 tahun $2013(<0,6 \mathrm{~g} / \mathrm{kg})$.

\section{CORRESPONDING AUTHOR}

Name: Zakiya Zar'a

Phone: +6281276820835

E-mail: kiyut13@gmail.com

\section{ARTICLE INFORMATION}

Received: September $23^{\text {rd }}$, 2020

Revised: October $15^{\text {th }}, 2020$

Available online: October $31^{\text {st }}, 2020$ 


\section{Pendahuluan}

Bahan tambahan pangan (BTP) adalah bahan yang ditambahkan ke dalam pangan untuk meningkatkan daya tahan produk, mempengaruhi sifat atau bentuk pangan, termasuk rasa, struktur dan penampilan. BTP tidak ditujukan untuk mengurangi nilai gizi pangan. ${ }^{1}$ Pengawet adalah zat yang ditambahkan pada makanan untuk mencegah dekomposisi oleh pertumbuhan mikroba ataupun bahan lain yang tidak diinginkan yang dapat menimbulkan perubahan pada makanan secara fisik. ${ }^{2}$ Natrium benzoat merupakan pengawet yang lebih sering digunakan karena kelarutannya mencapai 200 kali kelarutan asam benzoat di dalam air. ${ }^{3}$

Konsumsi natrium benzoat yang berlebihan dapat mengganggu pembelahan sel, karena natrium benzoat bersifat mutagenik dan sitotoksik terhadap sel limfosit sehingga dapat menyebabkan terbentuknya mikronukleus dan penghancuran kromosom. ${ }^{4}$ Keberadaan mikronukleus selanjutnya akan menghambat pembelahan sel, menyebabkan apoptosis sel. ${ }^{2}$ Saatci (2016) melakukan penelitian terhadap 16 ekor tikus mengandung dengan menambahkan natrium benzoat pada makanan tikus sebanyak 0 ; 0,$5 ; 1 ; 1,5 \mathrm{mg} / \mathrm{mL}$ setiap harinya dari usia kehamilan 0 hingga 20 hari. Hasilnya ditemukan adanya peningkatan mikronukleus pada tikus mengandung dan fetusnya. ${ }^{5}$

Paparan natrium benzoat sebesar 130-550 $\mathrm{mg} / \mathrm{kg} /$ hari menyebabkan adanya disfungsi serebral berupa defisit koordinasi, gangguan pada proses belajar dan mengingat, yang didasari oleh reaksi stres oksidatif.6,7 Penelitian yang dilakukan oleh McCann (2007) menunjukkan adanya kontribusi natrium benzoat terhadap gejala ADHD dan hiperaktifitas pada anak-anak. ${ }^{8}$

Pada tahun 2011 dilakukan penelitian oleh Fitriani (2011) menggunakan delapan sampel dari cabai merah giling yang dijual di Kota Malang. Kedelapan sampel positif mengandung natrium benzoate dengan kadar berkisar antara 319-491 mg/kg. Angka ini memenuhi persyaratan BPOM. ${ }^{9}$ Dalam beberapa penelitian yang dilakukan tehadap cabai merah giling yang dijual di pasar, masih banyak pengawet yang digunakan melebihi batas maksimal penggunaan BTP pengawet. Rosaini (2016) menggunakan cabai giling halus dari pasar tradisional di Payakumbuh, Bukittinggi dan Padang. Tiga dari enam sampel positif mengandung natrium benzoat, masing-masing berkisar $0,957 \mathrm{~g} / \mathrm{kg}, 0,976 \mathrm{~g} / \mathrm{kg}, 0,894 \mathrm{~g} / \mathrm{kg}$. Ketiga sampel tidak memenuhi persyaratan BPOM.10 Penelitian oleh Regina (2016), menggunakan cabai merah giling yang dijual di Pasar Raya Kota Padang, tiga dari enam sampel mengandung natrium benzoat, masing-masing berkisar 5,533 g/kg, 6,461 g/kg, 1,689 g/kg. Tiga dari enam sampel tersebut tidak memenuhi persyaratan BPOM.11 Penelitian ini bertujuan untuk mengetahui ada atau tidaknya pemakaian natrium benzoat pada cabai merah giling yang dijual di Pasar Raya Kota Padang beserta kadarnya.

\section{Metode}

Jenis penelitian ini adalah penelitian deskriptif dengan memberikan gambaran dan keterangan tentang kandungan natrium benzoat sebagai pengawet secara kualitatif dan kuantitatif pada cabai giling yang dijual di Pasar Raya Kota Padang. Hasil penelitian kemudian diolah dan dianalisis untuk diambil kesimpulannya. Penelitian dilakukan dari bulan September 2019 sampai Juli 2020 di UPTD Balai Laboratorium Kesehatan Sumatera Barat. Populasi penelitian ini adalah semua cabai merah giling berasal dari produsen berbeda yang dijual di Pasar Raya Kota Padang. Sampel penelitian adalah semua populasi dijadikan sebagai subjek penelitian dengan kriteria: cabai merah giling yang dijual oleh pedagang dengan produsen yang berbeda di Pasar Raya Kota Padang dan cabai merah giling yang berwarna merah cerah. Kriteria eksklusi subjek: cabai merah giling yang tidak bermerek.

Data diperoleh dari hasil uji kualitatif menggunakan pereaksi $\mathrm{FeCl}_{3} \quad 5 \%$ dan uji kuantitatif dengan spektrofotometer Uv-Visible pada sampel cabai merah giling.

Pemeriksaan sampel menggunakan ekstraksi dengan dietil eter yang dapat digunakan pada uji kualitatif dan kuantitatif. Analisis kualitatif menggunakan pereaksi $\mathrm{FeCl} 35 \%$ pada hasil ekstraksi yang menunjukan endapan warna merah kecoklatan menandakan bahwa sampel tersebut positif mengandung natrium benzoat. Analisis kuantitatif menggunakan spektrofotometer UV-Visible pada panjang gelombang $225,6 \mathrm{~nm}$. 
Hasil

Sebanyak 35 sampel cabai merah giling yang dijual di Pasar Raya Kota Padang diteliti di UPTD Balai Laboratorium Kesehatan Sumatera Barat. Pemberian label dilakukan pada setiap sampel cabai merah giling, selanjutnya dilakukan identifikasi kualitatif dan kuantitatif natrium benzoat.

Berdasarkan penelitian yang dilakukan di UPTD Balai Laboratorium Kesehatan Sumatera Barat didapatkan hasil sebagai berikut:

Tabel 1. Identifikasi Senyawa Natrium Benzoat Pada Cabai Merah Giling yang Dijual di Pasar Raya Kota Padang

\begin{tabular}{lcc}
\hline \multicolumn{1}{c}{ Identifikasi Kualitatif Sampel } & f & $\mathbf{~ \% ~}$ \\
\hline Positif & 35 & 100 \\
Negatif & 0 & 0 \\
\hline
\end{tabular}

Pada tabel 1 menunjukkan bahwa secara kualitatif didapatkan 35 sampel (100\%) positif mengandung natrium benzoat.

Tabel 2. Distribusi Sampel dan Kadar Natrium Benzoat pada Cabai Merah Giling yang Dijual di Pasar Raya Kota Padang

\begin{tabular}{lcccc}
\hline & $\begin{array}{c}\text { Rata-Rata } \\
\text { (g/kg) }\end{array}$ & $\begin{array}{c}\text { Standar } \\
\text { Deviasi }\end{array}$ & \multicolumn{2}{c}{ Kadar (g/kg) } \\
\cline { 2 - 5 } Sampel & 0,144 & 64,3 & 0,026 & 0,252 \\
\hline
\end{tabular}

Hasil penelitian secara kuantitatif menunjukkan bahwa dari 35 sampel positif mengandung natrium benzoat, menunjukkan kadar rata-rata berada di bawah standar ketetapan BPOM $(<0,6 \mathrm{~g} / \mathrm{kg})$.

Tabel 3. Distribusi Frekuensi Kadar Natrium Benzoat berdasarkan Standar Ketetapan BPOM pada Cabai Merah Giling yang Dijual di Pasar Raya Kota Padang

\begin{tabular}{lcc}
\hline Standar ketetapan BPOM $(<\mathbf{0 , 6} \mathbf{g} / \mathbf{k g})$ & $\mathbf{f}$ & $\mathbf{\%}$ \\
\hline Memenuhi & 35 & 100 \\
Tidak memenuhi & 0 & 0 \\
Total & 35 & 100 \\
\hline
\end{tabular}

Pada tabel 3 menunjukkan bahwa kadar natrium benzoat pada seluruh sampel $(100 \%)$ sesuai standar yang ditetapkan oleh BPOM $(\leq 0,6$ $\mathrm{g} / \mathrm{kg})$.

\section{Pembahasan}

Berdasarkan hasil penelitian yang dilakukan di UPTD Laboratorium Kesehatan Sumatera Barat, terhadap 35 sampel cabai merah giling yang diambil dari Pasar Raya Kota Padang menunjukkan bahwa 100\% sampel menggunakan natrium benzoat. Uji kuantitatif pada sampel memberikan hasil bahwa kadar natrium benzoat pada semua sampel tidak melebihi standar yang ditetapkan BPOM. Kadar natrium benzoat tertinggi pada sampel adalah $0,252 \mathrm{~g} / \mathrm{kg}$ dan kadar terendah pada sampel adalah $0,026 \mathrm{~g} / \mathrm{kg}$ dengan rata-rata keseluruhan $0,144 \mathrm{~g} / \mathrm{kg}$.

Penggunaan natrium benzoat pada sampel sesuai dengan standar yang ditetapkan oleh Peraturan Kepala BPOM nomor 36 tahun 2013 mengenai batas maksimal penggunaan bahan tambahan pangan berupa pengawet pada bumbu yaitu $0,6 \mathrm{~g} / \mathrm{kg}$, dengan kadar natrium benzoat maksimal sebesar 0,6 g/kg dalam $1 \mathrm{~kg}$ cabai merah giling. ${ }^{1}$

Hasil ini sejalan dengan penelitian sebelumnya oleh Fitriani (2011) yang dilakukan pada delapan sampel cabai merah giling yang dijual di Kota Malang, hasilnya menunjukkan $100 \%$ sampel positif natrium benzoat dengan kadar berkisar diantara 0,319-0,491 g/kg. Perbandingan penelitian sebelumnya dengan penelitian saat ini menunjukkan bahwa dari tahun 2011 hingga tahun 2020, masih banyak pedagang cabai merah giling yang menggunakan natrium benzoat sebagai pengawet, meskipun kadarnya rendah. Hal ini memungkinkan penggunaan natrium benzoat digunakan oleh pedagang cabai giling untuk menjaga kualitas cabai sehingga tidak cepat rusak dan membusuk agar tetap dapat dijual, meskipun disimpan selama beberapa hari. Dilihat dari peran natrium benzoat pada cabai giling yang mampu menghambat pertumbuhan mikroorganisme sehingga proses oksidasi tertunda dan nutrisi cabai giling lebih terjaga. ${ }^{12}$ Natrium benzoat pada pangan bekerja dengan menurunkan $\mathrm{pH}$ sel mikroba, melalui proses disosiasi molekul benzoat pada lipid membran mikroba dan menghasilkan ion-ion hidrogen, menyebabkan aktivitas metabolisme sel terganggu sehingga sel mikroba tidak mampu membelah, pada akhirnya mengalami apoptosis. ${ }^{13}$ Akan tetapi penggunaan natrium benzoat terusmenerus dan konsumsi oleh masyarakat yang berkepanjangan memungkinkan timbulnya dampak berbahaya pada kesehatan konsumen secara kronis. Perlu dipikirkan untuk menggunakan bahan tambahan pangan yang alami atau menyarankan masyarakat untuk mengolah sendiri cabai merah giling sesuai 
kebutuhan tanpa menggunakan natrium benzoat sebagai pengawet.

Walaupun kadar yang diperoleh berada pada range normal, tetapi jika konsumen terpapar secara terus menerus tetap akan memberikan efek terhadap tubuh, seperti gejala ADHD, hiperaktifitas, gangguan pembelahan sel, kerusakan hati dan ginjal. 4,6,7,14,18

Konsumsi natrium benzoat yang sesuai standar ataupun tidak sesuai standar tetap memberikan efek buruk terhadap kesehatan manusia. Natrium benzoat di dalam tubuh akan dimetabolisme di hati, berkonjugasi dengan glisin kemudian menghasilkan senyawa asam hipurat $\left(\mathrm{C}_{9} \mathrm{H}_{9} \mathrm{NO}_{3}\right)^{4}$. Terbentuknya asam hipurat melalui ikatan glisin dan natrium benzoat akan menyebabkan timbulnya kondisi hipoglisinemia. Penurunan kadar glisin di dalam darah menyebabkan berkurangnya ikatan antara reseptor NMDA dan asam amino glisin, ikatan ini memiliki pengaruh pada peningkatan fungsi kognitif, memodulasi perhatian dan kebiasaan. Dengan berkurangnya ikatan ini dapat memicu gejala ADHD dan hiperaktivitas, dapat terjadi pada anak-anak dan dewasa. ${ }^{14}$ Penelitian yang dilakukan terhadap 153 anak berusia 3 tahun dan 144 anak berusia 8-9 tahun, dengan memberikan minuman mengandung $45 \mathrm{mg}$ natrium benzoat selama enam minggu. Hasil tes menunjukkan adanya keterkaitan perlakuan dengan munculnya gejala ADHD pada anak-anak. ${ }^{8}$ Penelitian yang dilakukan terhadap 475 mahasiswa dengan mengecualikan sampel yang sudah memiliki gejala ADHD, dalam pengobatan ADHD dan yang mengonsumsi obatobat psikotoprika dan tryptophan. Penelitian ini menggunakan skala Adult Self-Report Scale Version I.I (ASRS-VI.I) dengan melihat hubungan antara konsumsi minuman mengandung natrium benzoat dengan skor yang didapatkan dari skala tersebut. Hasil penelitian menunjukkan bahwa 67 sampel mendapat skor $\geq 4$ menunjukkan gejala ADHD, semuanya mengonsumsi minuman mengandung natrium benzoat lebih banyak dibandingkan sampel yang memiliki skor lebih rendah $(\leq 4) .15$

Terhadap sel, natrium benzoat dapat bersifat mutagenik dan sitotoksik, menyebabkan terbentuknya mikronukleus, penghancuran kromosom dan apoptosis sel. ${ }^{4}$ Pemberian 2 $\mathrm{mg} / \mathrm{mL}$ natrium benzoat pada sel menyebabkan terbentuknya mutasi kromosom, diantaranya sister chromatid separation, chromosome gaps, chromosome ring, fragment polyploidy. Kromosom sel yang yang bermutasi tidak mengandung sentromer, sehingga pada proses pembelahan sel fase metafase-anafase, kromosom tersebut tidak dapat ditarik ke kutub. Pada telofase, kromosom yang berada di kutub maupun yang tertinggal akan mengalami proses pembentukan membran inti. Mitosis selesai dengan menghasilkan dua sel yang masingmasingnya mengandung inti utama dan mikronukleus. Keberadaan mikronukleus pada setiap sel ini yang akan menghambat proses pembelahan berikutnya, sel akhirnya mengalami apoptosis. $^{2}$

Saatci et al. (2016) melakukan percobaan terhadap 16 ekor tikus mengandung dengan menambahkan natrium benzoat pada makanan tikus selama 20 hari sebanyak $0 ; 0,5 ; 1 ; 1,5$ $\mathrm{mg} / \mathrm{mL}$. Ditemukan peningkatan mikronukleus pada fetus dan induknya. ${ }^{5}$ Percobaan terhadap kompleks protein NFKB oleh Yilmaz et al. (2018) menunjukkan peran natrium benzoat dalam menghambat aktivitas NFKB sel imun sistem saraf pusat pada konsentrasi nontoksik dan menurunkan ekspresi NFKB dalam jaringan hati tikus. ${ }^{16}$ Dampak natrium benzoat terhadap sel juga terlihat melalui mekanisme stres oksidatif. Penelitian dilakukan terhadap sel darah merah secara in vitro. Hasilnya menunjukkan peningkatan pembentukan senyawa malondialdehid $\left(\mathrm{CH}_{2}(\mathrm{CHO})_{2}\right)$ yang merupakan indikator stres oksidatif, juga dengan berkurangnya enzim glutation peroksidase yang berperan sebagai enzim antioksidan, berfungsi untuk melindungi suatu organisme dari kerusakan akibat stres oksidatif. ${ }^{17}$

Natrium benzoat memiliki efek terhadap hati dan ginjal. Bakar (2014) melakukan penelitian terhadap 10 tikus dengan memberikan natrium benzoat sebanyak $2442 \mathrm{mg} / \mathrm{kg}$ berat badan per hari selama 10 hari. Dibandingkan dengan tikus kontrol, tikus yang mengonsumsi natrium benzoat menunjukkan perubahan degeneratif pada struktur jaringan histologi hati dan ginjal. Jaringan hati mengalami vakuolisasi dan kehilangan nukleus, hepatosit hipertrofi, ireguler dan mengalami degenerasi dan disorganisasi. Natrium benzoat pada ginjal menghilangkan krista mitokondria sel, penggabungan membran luar mitokondria, kromatin menjadi ireguler, dan 
ginjal mengalami vakuolisasi. ${ }^{18}$ Lennerz (2015) pada penelitiannya menemukan adanya peningkatan asam antranilat dengan konsumsi natrium benzoat, asam antranilat yang terakumulasi di dalam tubuh diduga kuat berkaitan dengan kerusakan ginjal melalui mekanisme kerusakan sel mesangial. Kerusakan ginjal akan berpengaruh pada akumulasi asam hipurat karena kegagalan ekskresi. ${ }^{19}$

Hasil penelitian ini tidak sejalan dengan penelitian yang dilakukan oleh Rosaini (2016) menggunakan cabai merah giling yang diambil dari pasar tradisional di Payakumbuh, Bukittinggi dan Padang. Tiga dari enam sampel terbukti positif mengandung natrium benzoat dengan kadar masing-masing melebihi standar ketetapan BPOM, berkisar 0,957 g/kg, 0,976 g/ kg, 0,894 g/kg. ${ }^{10}$ Hal serupa pada penelitian yang dilakukan oleh Regina (2016) menggunakan cabai merah giling yang djual di Pasar Raya Kota Padang. Tiga dari enam sampel yang terbukti positif mengandung natrium benzoat memiliki kadar yang melebihi standar ketetapan BPOM, masingmasing berkisar 5,533 g/ kg, 6,461 g/ $\mathrm{kg}$, $1,689 \mathrm{~g} / \mathrm{kg} \cdot{ }^{11}$

Perbandingan penelitian yang dilakukan oleh Regina (2016) dengan penelitian yang penulis lakukan pada tahun 2020 di lokasi pengambilan sampel yang sama yaitu Pasar Raya Kota Padang menunjukkan adanya penurunan kadar natrium benzoat pada cabai merah giling seiring berjalannya waktu. Mungkin ini merupakan bentuk hasil dari edukasi yang dilakukan oleh BPOM kepada masyarakat. ${ }^{20}$ Untuk itu diperlukan edukasi yang dilakukan secara reguler, agar penggunaan natrium benzoat pada cabai merah giling dapat terus berkurang dan terkontrol. Selain itu, kemungkinan adanya beberapa faktor pembeda yang memengaruhi, seperti faktor pengolahan cabai giling, diantaranya perbedaan pengolah dan proses pengolahan cabai, perbedaan bahan olahan dan hasil bahan olahan cabai, juga proses penambahan pengawet yang tidak terstandar, dan kadar pengawet terutama natrium benzoat yang tidak tetap dari penjual cabai giling.

\section{Simpulan}

Berdasarkan hasil penelitian ini didapatkan kesimpulan bahwa seluruh cabai merah giling halus yang menjadi sampel, positif mengandung natrium benzoat sebagai pengawet dengan kadar yang memenuhi ketetapan dalam Peraturan Kepala BPOM nomor 36 tahun 2013.

\section{Ucapan Terima Kasih}

Terima kasih penulis sampaikan kepada semua instansi yang telah membantu penyelesaian penelitian ini terutama UPTD Balai Laboratorium Kesehatan Sumatera Barat.

\section{Daftar Pustaka}

1. BPOM RI. Peraturan kepala badan pengawas obat dan makanan republik indonesia no. 36 tahun 2013 tentang batas maksimum penggunaaan bahan tambahan pangan pengawet. 2013.

2. Pongsavee M. Effect of sodium benzoate preservative on micronucleus induction, chromosome break, and ala40thr superoxide dismutase gene mutation in lymphocytes. 2015.

3. Sangeetha. Analytical method development for sodium benzoate and its application to soft drinks and fruit juices (Disertasi). College of Pharmacy Sri Ramakrishna Institute of Paramedical Sciences; 2016.13.

4. International Programme on Chemical Safety's Concise International Chemical Assessment Documents. Number 26: Benzoic acid and sodium benzoate. 2000;39.

5. Saatci C, Erdem Y, Bayramov R, Akalın H, Tascioglu N, Ozkul Y. Effect of sodium benzoate on DNA breakage, micronucleus formation and mitotic index in peripheral blood of pregnant rats and their newborns. Biotechnol Equip. 2016;30(6):1179-83.

6. Khoshnoud M, Siavashpour A, Bakhshizadeh M, Rashedinia M. Effects of sodium benzoate, a commonly used food preservative, on learning, memory, and oxidative stress in brain of mice. 2017.

7. Sharafati F, Arian A, Sharafati R. Assessment of sodium benzoate and potassium sorbate preservatives in some products in Kashan, Iran with estimation of human health risk. Food Chem Toxicol. 2018;120:634-8.

8. Mccann D, Barrett A, Cooper A, Crumpler D, Dalen L, Grimshaw K, et al. Food additives and hyperactive behaviour in 3-year-old and 8/9-year-old children in the community: a randomised, double-blinded, placebo-controlled trial. 2007;370.

9. Fitriani E. Studi Keamanan Pangan Pada Cabe Giling Di Pasar Tradisional Di Kota Malang: Kajian Bahan Pewarna, Pengawet Sintetis dan Total Mikroba (Thesis). Fakultas Teknologi Pertanian. Universitas Brawijaya; 2011.

10. Higea JF, Rosaini H, Yuliana S. Penetapan kadar natrium benzoat pada cabai giling halus (Capsicum annuum Linn.) secara spektrofotometri uv-vis. 2016;8(1).

11. Regina A, Martinus B A, Yudhea G P. Pengembangan dan validasi metode analisis zat pengawet natrium benzoat pada cabe merah giling secara spektrofotometri ultraviolet. Scientia Jur Farmasi dan Kesehat. 2016;6:133.

12. Davidson PM, Sofos JN, Branen AL, editors. Antimicrobials in food. 3rd ed. Boca Raton: Taylor \& Francis Group; 2005. 720 p.

13. Oktoviana Y, Aminah S, Sakung J. Pengaruh lama penyimpanan dan konsentrasi natrium benzoat 
terhadap kadar vitamin c cabai merah (Capsicum annuum L). J Akad Kim. 2012;1(4):193-9.

14. Piper PW. Potential safety issues surrounding the use of benzoate preservatives. Beverages. 2018;4(33):17.

15. Beezhold BL, Johnston CS, Nochta KA. Sodium benzoate-rich beverage consumption is associated with increased reporting of ADHD symptoms in college students: a pilot investigation. J Atten Disord. 2014;18(3):236-41.

16. Yilmaz B, Karabay Z. Food additive sodium benzoate $(\mathrm{NaB})$ activates $\mathrm{NF \kappa B}$ and induces apoptosis in HCT116 cells. Molecules. 2018;23(723):1-14.

17. Noorafshan A, Erfanizadeh M, Karbalay-Doust S. Stereological studies of the effects of sodium benzoate or ascorbic acid on rats' cerebellum. Saudi Med J. 2014;35(12):1494-500.

18. Bakar E. Effects of sodium benzoate and citric acid on serum , liver and kidney tissue total sialic acid levels : an ultrastructural study. J Appl Biol Sci. 2014;8(2):915.

19. Lennerz B, Vafai SB, Delaney NF, Clish CB, Deik AA, Pierce KA, et al. Effects of sodium benzoate, a widely used food preservative, on glucose homeostasis and metabolic profiles in humans. Mol Genet Metab. 2015;114(1):73-9.

20. BPOM RI. Laporan Tahunan Badan POM Padang 2018. 